\title{
Dentigerous cyst in the maxilla: case report in a pediatric patient
}

\author{
Cisto dentígero em maxila: relato de caso em paciente pediátrico \\ Quiste dentígero en el maxilar: informe de un caso en un paciente pediátrico
}

Received: 11/14/2021 | Reviewed: 11/24/2021 | Accept: 11/28/2021| Published: 12/09/2021

Bianca de Fatima Borim Pulino ORCID: https://orcid.org/0000-0003-0519-3246

São Paulo State University; Brazil

E-mail: bianca.pulino@unesp.br

Raphael Capelli Guerra

ORCID: https://orcid.org/0000-0002-5478-9727

São Paulo Metodista University, Brazil

E-mail: dr.raphael.guerra@gmail.com

Gabriel Cunha Collini

ORCID: https://orcid.org/0000-0002-9071-7827

Leforte Group, Brazil

E-mail: gabrielccollini@gmail.com

Marcello Cheloti

ORCID: https://orcid.org/0000-0002-5526-1262

Leforte Group, Brazil drcheloti@yahoo.com.br

E-mail: gabrielccollini@gmail.com

Eduardo Hochuli Vieira

ORCID: https://orcid.org/0000-0003-4040-9313

São Paulo State University; Brazil

E-mail: eduardo.hochuli@unesp.br

\begin{abstract}
Dentigerous cysts are the second most common odontogenic cysts of the jaws, and sometimes inhibit the eruption of teeth. Almost all of the dentigerous cyst encloses the crown of an unerupted tooth and the radiolucent area is attached to the tooth at the cementoenamel junction. Dentigerous cyst is more common in male patients and most commonly develop in the second and third decades of life. Clinically, a localized swelling of the alveolar bone can be detected, however, dentigerous cysts can be asymptomatic during a long period of time, leading to a significant destruction of bone. The conventional treatment plan is cyst removal and marsupialization. Marsupialization therapy can be useful to promote the spontaneous eruption of the involved tooth within the cyst. However, tooth eruption does not always occur spontaneously after marsupialization. This article aims to report a clinical case of the diagnosis and treatment of a dentigerous cyst in the maxilla associated with an unerupted canine in a pediatric patient and discussion of the treatment performed.
\end{abstract}

Keywords: Dentigerous cyst; Tooth unerupted; Multidisciplinary approach.

\section{Resumo}

Os cistos dentígeros é o segundo cisto odontogênico mais comuns dos maxilares, e às vezes inibem a erupção dos dentes. Quase todos os cistos dentígeros envolvem a coroa de um dente não irrompido e a área radiolúcida está localizada na junção do cemento e esmalte. O cisto dentígro é mais comum em pacientes do sexo masculino e normalmente se desenvolve na segunda e terceira décadas de vida. Clinicamente, um aumento de volume localizado do osso alveolar pode ser detectado, entretanto, os cistos dentígrados podem ser assintomáticos durante um longo período de tempo, levando a uma destruição significativa do osso. O plano de tratamento convencional é a remoção de cistos e marsupialização. A terapia de marsupialização pode ser útil para promover a erupção espontânea do dente envolvido dentro do cisto. Entretanto, a erupção do dente nem sempre ocorre espontaneamente após a marsupialização. Este artigo visa relatar um caso clínico do diagnóstico e tratamento de um cisto dentígero na maxila associado a um canino não irrompido em um paciente pediátrico e a discussão do tratamento realizado.

Palavras-chave: Cisto dentígero; Dente não erupcionado; Abordagem multidisciplinar.

\section{Resumen}

Los quistes dentígeros son los segundos quistes odontogénicos más comunes de los maxilares, y a veces inhiben la erupción de los dientes. Casi todo el quiste dentígero encierra la corona de un diente no erupcionado y la zona radiolúcida está unida al diente en la unión cemento-esmalte. El quiste dentígero es más común en pacientes masculinos y se desarrolla con mayor frecuencia en la segunda y tercera décadas de la vida. Clínicamente, se puede detectar una inflamación localizada del hueso alveolar, sin embargo, los quistes dentígeros pueden ser asintomáticos durante un largo periodo de tiempo, lo que conlleva una importante destrucción del hueso. El plan de tratamiento convencional es la 
extirpación del quiste y la marsupialización. La terapia de marsupialización puede ser útil para promover la erupción espontánea del diente afectado dentro del quiste. Sin embargo, la erupción del diente no siempre ocurre espontáneamente después de la marsupialización. Este artículo tiene como objetivo reportar un caso clínico del diagnóstico y tratamiento de un quiste dentígero en el maxilar asociado a un canino no erupcionado en un paciente pediátrico y la discusión del tratamiento realizado.

Palabras clave: Quiste dentígero; Diente no erupcionado; Planteamiento multidisciplinar.

\section{Introduction}

The tooth development results from the interaction of several steps between oral epithelium and mesenchymal tissue. Abnormal tissue interaction during development can eventually result in ectopic development of tooth eruption. (Buyukkurt et al., 2010). Ectopic eruption can be a result of to one of these 3 processes: developmental disorder, iatrogenic activity, or pathological process such as a tumor or cyst.(Patil et al., 2019)

Dentigerous cysts are considered the second most common odontogenic cysts of the jaws and can inhibit the eruption of teeth. Almost all dentigerous cysts are localized in intimate contact with the crown of an unerupted tooth and the radiolucent area is in contact with the tooth at the cemento-enamel junction. It appears as a well-defined radiolucent odontogenic lesion that involves the crown of an unerupted tooth, causing difficulty in its eruption. This cyst is associated with teeth that develop impaction, such as third molars and canines, and can also affect unerupted supernumerary teeth and even odontomas.. (Ustuner et al., 2003)

Dentigerous cysts involving impacted teeth usually displace these teeth into ectopic positions. In the maxilla, these teeth may be displaced into the maxillary sinus. Dentigerous cysts progress slowly and develop for several years without showing symptoms. When the maxillary sinus is invaded, symptoms usually occur after a few years. The sequelae of these cysts can lead to sinus obstruction.(Lacerda et al., 2018)

The best hypothesis for the formation of a dentigerous cyst indicates an accumulation of fluid, originating from the increased pressure exerted by a possibly erupting tooth on the follicle, either between the reduced epithelium or between the epithelium layers of the enamel organ. (Contar et al., 2015).

Dentigerous cyst is more common in male patients and may develop in the second and third decades of life. Clinically, a localized bulging of the alveolar bone can be detected, however, dentigerous cysts can be asymptomatic for a long period of time, leading to significant bone destruction. (Ustuner et al., 2003)

Dentigerous cysts are characterized by unilocular radiolucent areas associated with the crowns of unerupted teeth at the level of the cemento-enamel junction. The radiolucent lesion is well defined and circumscribed with a sclerotic (radiopaque) border. (Meningaud et al., 2006)

The dentigeron cyst may have secondary infection, irregular margins, or poorly defined borders. The roots of adjacent teeth can show resorption or displacement caused by pressure from the dentigerous cysts. Larger cysts may have a multiloculated appearance and be considered in the differential diagnosis of ameloblastoma.(Meningaud et al., 2006)

Microscopically, a thin (2-3 layers) non-keratinized cystic epithelium is observed. The fibrous capsule is loosely arranged and may have islands of inactive-looking odontogenic epithelial cells. Inflamed dentigerous cysts may present multilayered cystic epithelium.(Patil et al., 2019)

Conventional treatment is removal of the cyst through marsupialization. This treatment method can be helpful in promoting the spontaneous eruption of the tooth involved within the cyst. Nevertheless, the eruption of the tooth may not necessarily happen spontaneously after marsupialization. (Aoki et al., 2018)

This article aims to report a clinical case of the diagnosis and treatment of a dentigerous cyst in the maxilla associated with an unerupted canine in a pediatric patient and discussion of the treatment performed. 


\section{Methodology}

This clinical case report is part of a descriptive observational study, which in addition to discussing the proposed treatment, also aimed to discuss the topic through the bibliographic survey carried out (Pereira, A. S., 2018) and thus contribute to the scarce scientific literature on the subject.

Thus, representing a descriptive and qualitative content. The case was conducted according to clinical and professional ethics. The patient reported in the study has a personal data sheet and anamnesis, where he authorized the use of images, clinical, radiographic, and socioeconomic data for educational and research purposes, and with this signed a Free and Informed Consent Form and the Informed Consent Form. Consent of the Person's Participation as a Subject, which were duly read and explained.

\section{Case Report}

Patient E.F.O, 10 years old, male, was accompanied by his parents to the Oral and Maxillofacial Surgery Outpatient Clinic of the Leforte Group, referring volume increase in the right maxilla region for 4 months and with progressive worsening. Clinical examination revealed an extra-oral swelling in the middle third of the right face, with erasure of the nasolabial groove. Intraoral examination revealed bulging of the vestibule in the region of tooth 13 , which had not erupted and the patient reported pain on palpation.

A computed tomography scan of the face was requested for further evaluation. Upon the patient's return, a hypodense, circumscribed lesion with a well-defined halo of approximately $28.15 \times 18,50 \mathrm{~mm}$ was observed in the right pre-maxilla region, with complete involvement of tooth 13 within the lesion. According to the clinical and imaging features, the diagnostic hypothesis was a dentigerous cyst. (Figure 1 and 2)

Figure 1 - A computed tomography scan axial of the face showing a hypodense, circumscribed lesion with a well-defined halo of approximately $28.15 \times 18,50 \mathrm{~mm}$ was observed in the right pre-maxilla region.

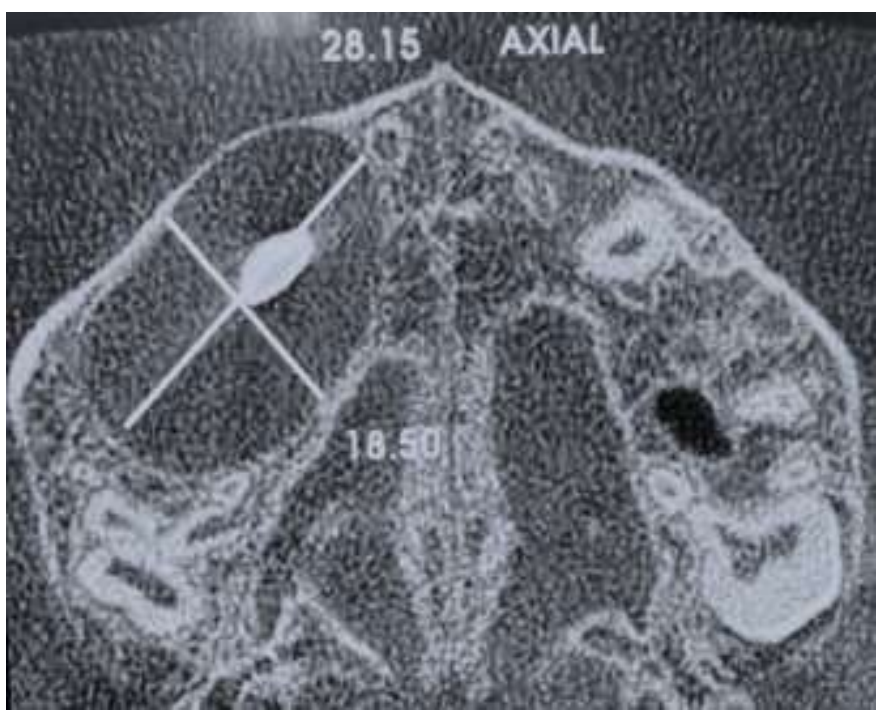

Source: Authors. 
Figure 2 - A computed tomography scan sagital of the face showing a hypodense, circumscribed lesion with a well-defined halo was observed in the right pre-maxilla region.

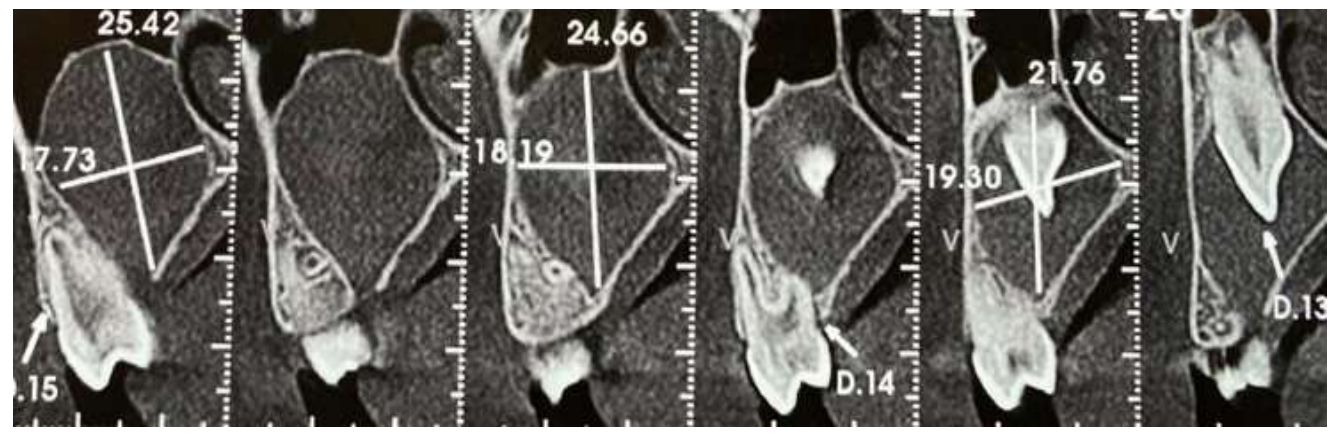

Source: Authors.

It was decided to perform the surgical procedure under general anesthesia for enucleation of the cystic capsule and exodontia of tooth 13 , due to malposition and making orthodontic traction unfeasible. (Figure 3)

Figure 3 - The surgical procedure under general anesthesia for enucleation of the cystic capsule and exodontia of tooth 13.

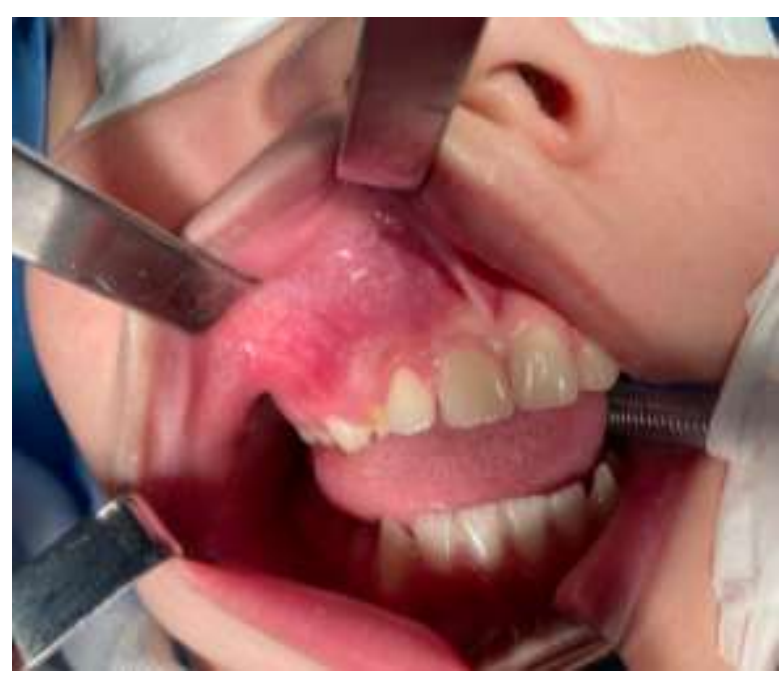

Source: Authors.

The procedure was performed under general anesthesia, with infiltrative local anesthesia in the right upper sulcus with lidocaine, incision and displacement of the mucoperiosteal flap to access the cystic capsule, followed by enucleation of the cystic capsule and exodontia of tooth 13. (Figure 4) 
Figure 4 - The incision and displacement of the mucoperiosteal flap to access the cystic capsule, followed by enucleation of the cystic.

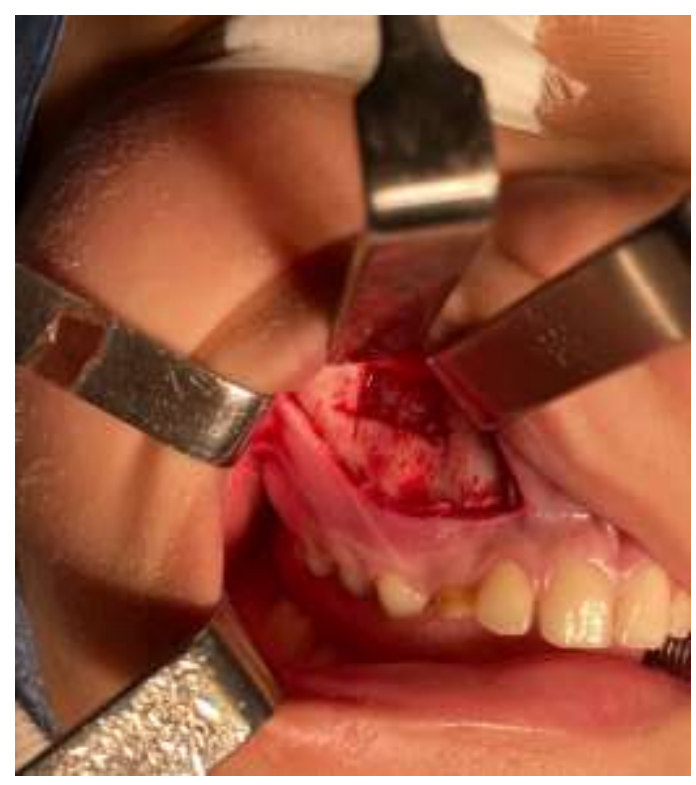

Source: Authors.

The surgical specimen was sent for pathological anatomic examination with the following description, presence of thin cystic epithelium of approximately 3 non-keratinized layers. Scattered mucous cells can and fibrous capsule with small odontogenic epithelial islands.

We opted for curettage of the surgical site to remove the cystic capsule, extraction the tooth and refinement of the remaining bone borders. Repositioning and inter papillary suture of the flap were performed. (Figure 5)

Figure 5 - The cystic capsule and tooth 13 after extration.

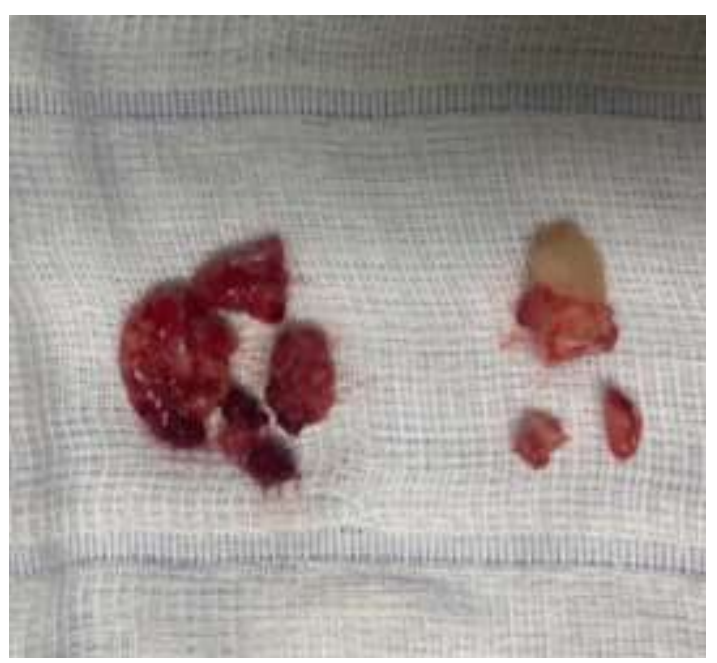

Source: Authors.

The patient is being followed up as an outpatient, and a computed tomography of the 6-month postoperative period shows satisfactory bone formation at the site of the enucleation of the dentigerous cyst and no signs of recurrence. (Figure 6)

Patient does not report symptoms and remains under outpatient follow-up. 
Figure 6 - The computed tomography of the 6-month postoperative period shows satisfactory bone formation at the site of the enucleation of the dentigerous cyst and no signs of recurrence.

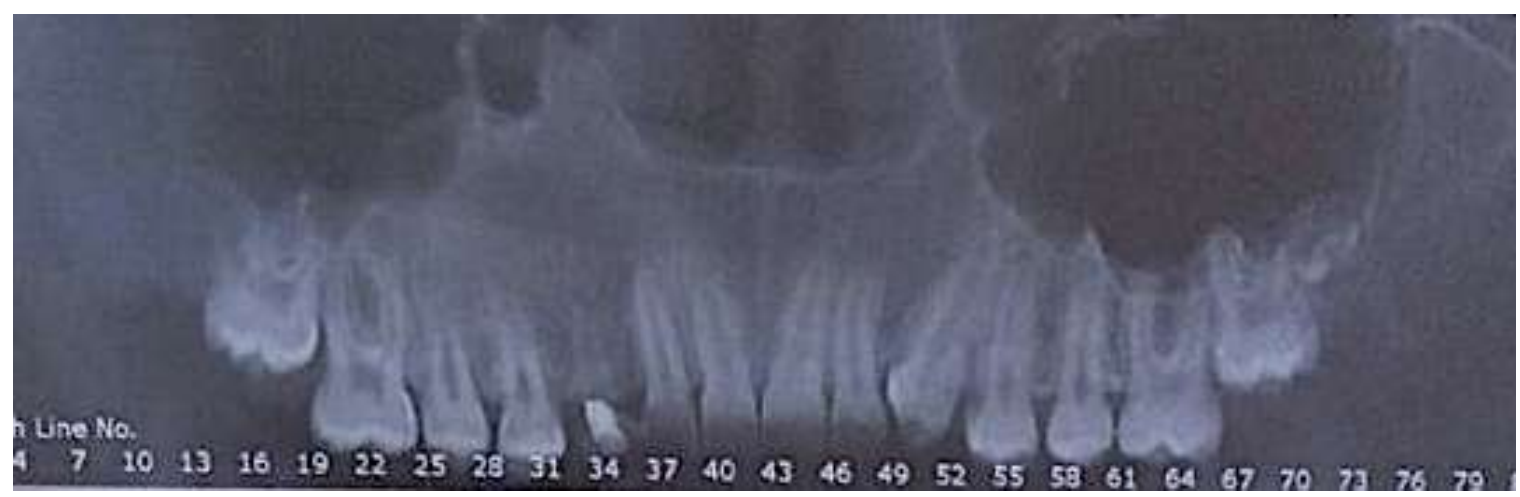

Source: Authors.

\section{Discussion}

The vast majority have involvement with the crown of an unerupted tooth and the radiolucent area is closely attached to the tooth at the junction of the cementum and enamel. (Ustuner et al., 2003)

Cysts occur due to accumulation of fluid between the crown of the unerupted tooth and the follicular epithelium (reduced enamel epithelium). (Patil et al., 2019)

The dentigerous cyst may exhibit irregular margins or ill-defined borders, and it is possible to observe the roots of adjacent teeth a resorption or displacement caused by the pressure of the cysts during their development. Large cysts can have a multiloculated appearance and can be considered in the differential diagnosis of ameloblastoma. There are three types of radiographic features usually noted in dentigerous cysts: central, lateral, and circumferential. The most found radiographic feature is a radiolucent cavity that surrounds the crown of an unerupted tooth. The lateral variant, on the other hand, is characterized by a radiolucent appearance observed laterally along the root and encompasses part of the crown of the unerupted tooth. In the circumferential variant, it is a real challenge to diagnose a dentigerous cyst, because the radiolucent cavity involves the entire tooth. Most practitioners are aware of the fact that the radiolucent cavity is associated with the crown of an unerupted tooth extending to the level of the cemento-enamel junction..(Meningaud et al., 2006)

Microscopically, a non-keratinized epithelium composed of 2 to 3 thin layers is observed. Scattered mucous cells are observed and a fibrous capsule is freely arranged and may present small odontogenic epithelial islands of inactive appearance. In inflamed dentigerous cysts it is possible to observe a non-keratinized cystic epithelium with several layers and hyperplastic. Some associations to dentigerous cysts are: ameloblastoma due to the possibility of a potential transformation of nests of odontogenic epithelial cells, mucoepidermoid carcinoma, characterized as a malignant tumor of the salivary glands which can arise through the alteration of mucous cells observed in the lining epithelium of the cyst, and squamous cell carcinoma of the lining epithelium.(Gadbail et al., 2012) (Thompson, 2018)

According to Babu and Santosh (2020) we can include unicystic ameloblastoma as a differential diagnosis, ameloblastic fibroma can also be considered when in younger individuals. However, adenomatoid odontogenic tumor can be considered with differential diagnosis of dentigerous cyst due to pericoronal radiolucency observed mainly in upper or lower canines. However, mucoceles, retention cysts and pseudocysts are also included in the differential diagnosis when a lesion is observed in the maxillary sinus and generating maxillary expansion. (Ustuner et al., 2003)(Dağistan et al., 2007) (Babu \& Santosh, 2020)

The lack of correlation between the expression of apoptosis-related factors and cell proliferation markers in dental follicles suggests that the stage of impaction and pericoronal radiolucency did not significantly correlate with the expression of 
apoptosis-related factors or cell proliferation markers. The Ki-67-LI marker of dental follicles with positivity in epithelium during proliferation was significantly higher than the Ki-67-LI of epithelium with other morphological characteristics, indicating a high proliferative potential. Dental follicles with inflammatory changes had significantly higher ssDNA-LI and Ki-67-LI than Ki-67-LI of epithelium with other morphological features, indicating a high proliferative potential. Dental follicles with these characteristics suggest that inflammatory changes regulate cell turnover of the epithelial components of the dental follicle..(Edamatsu et al., 2005)

Marsupialization is a surgical procedure that reduces the intracystic pressure and gradually leads to cyst reduction. This procedure causes a cavity in the cyst wall to drain the liquid content of the cyst, and sometimes the cyst wall is sutured to the oral mucosa.. The benefit of this method is the ability to promote eruption of the tooth associated with the cyst, with or without orthodontic traction. However, its limitations are the long postoperative duration of treatment and the inconvenience of keeping the wound open. (Ertas \& Yavuz, 2003)

It is a consensus that marsupialization and orthodontic traction are the best treatment option for the patient with a dentigerous cyst that includes an unerupted tooth. Orthodontic traction of unerupted teeth is usually performed after marsupialization, when there is enough space for eruption. Some studies have been developed to establish the adequate moment for orthodontic traction. The results obtained were that the spontaneous eruption of the tooth associated with the cyst is predictable within 3 months after marsupialization; however, orthodontic traction may be required for a longer period of time in some cases. (Karamanis et al., 2006) (Caliento et al., 2013)

We believe that enucleation is an effective type of treatment, as is marsupialization; however, when it is observed that there is no possibility of dental traction, as in the case described in this article, we opt for enucleation for a faster and more resolutive treatment.

The prognostic factors for eruption of a cyst associated tooth after marsupialization are debatable. Some authors have reported that numerous factors affect tooth eruption, including patient age, depth, inclination, stage of root formation (open or closed apex) and space availability. (Sumer, Baş, \& Yildiz, 2007) In contrast, other authors state that these elements are not significant and do not affect tooth eruption. (McCrea, 2009) Primarily, the goal of the treatment method is marsupialization and tooth eruption with or without the use of orthodontic traction. The explanation for the failure of orthodontic traction is that the tooth axis with severe lingual tipping of the canine may prevent the eruption of the canine. (Aoki et al., 2018)

\section{Conclusion}

The treatments described in the literature, such as marsupialization, are very effective and have been used in surgical procedures with satisfactory results. However, we believe that enucleation is a type of effective treatment, as well as marsupialization; however, when it is observed that there is no possibility of dental traction, as in the case described in this article, we opted for enucleation for a faster and more resolutive treatment. However, we believe that more prospective studies related to the comparison of success rates are needed, when comparing the types of treatment available for this pathology.

\section{References}

Aoki, N., Ise, K., Inoue, A., Kosugi, Y., Koyama, C., Iida, M., Mitsudo, K. (2018). Multidisciplinary approach for treatment of a dentigerous cyst Marsupialization, orthodontic treatment, and implant placement: A case report. Journal of Medical Case Reports, 12(1), 1-7. https://doi.org/10.1186/s13256018-1829-2

Babu, A., \& Santosh, R. (2020). Odontogenic Cysts. 64, 105-119. https://doi.org/10.1016/j.cden.2019.08.002

Buyukkurt, M. C., Omezli, M. M., \& Miloglu, O. (2010). Dentigerous cyst associated with an ectopic tooth in the maxillary sinus: a report of 3 cases and review of the literature. Oral Surgery, Oral Medicine, Oral Pathology, Oral Radiology and Endodontology, 109(1), 67-71. https://doi.org/10.1016/j.tripleo.2009.07.043

Caliento, R., Mannarino, F. S., \& Hochuli-Vieira, E. (2013). Cisto dentígero: modalidades de tratamento. Revista de Odontologia Da UNESP, 42(6), 458-462. https://doi.org/10.1590/s1807-25772013000600012 
Contar, C. M. M., Thomé, C. A., Pompermayer, A., Sarot, J. R., Vinagre, R. O., \& Machado, M. Â. N. (2015). Marsupialization of Dentigerous Cyst: Report of a Case. Journal of Maxillofacial and Oral Surgery, 14, 4-6. https://doi.org/10.1007/s12663-011-0172-6

Dağistan, S., Cakur, B., \& Göregen, M. (2007). A dentigerous cyst containing an ectopic canine tooth below the floor of the maxillary sinus: a case report. Journal of Oral Science, 49(3), 249-252. https://doi.org/10.2334/josnusd.49.249

Edamatsu, M., Kumamoto, H., Ooya, K., \& Echigo, S. (2005). Apoptosis-related factors in the epithelial components of dental follicles and dentigerous cysts associated with impacted third molars of the mandible. Oral Surgery, Oral Medicine, Oral Pathology, Oral Radiology, and Endodontics, 99(1), 17-23. https://doi.org/10.1016/j.tripleo.2004.04.016

Ertas, Ü., \& Yavuz, M. S. (2003). Interesting eruption of 4 teeth associated with a large dentigerous cyst in mandible by only marsupialization. Journal of Oral and Maxillofacial Surgery, 61(6), 728-730. https://doi.org/10.1053/joms.2003.50145

Gadbail, A. R., Patil, R., \& Chaudhary, M. (2012). Co-expression of Ki-67 and p53 protein in ameloblastoma and keratocystic odontogenic tumor. Acta Odontologica Scandinavica, 70(6), 529-535. https://doi.org/10.3109/00016357.2011.600714

Karamanis S, Kitharas T, Tsoukalas D, P. N. (2006). Implant placement after marsupialization of a dentigerous cyst. J. J Oral Implantol., 32(6), $313-316$.

Lacerda, É. P. de M., Martorelli, S. B. de F., \& Martorelli, F. de O. (2018). Dentigerous cyst in the maxillary posterior region associated with an impacted deciduous molar. RGO - Revista Gaúcha de Odontologia, 66(2), 194-198. https://doi.org/10.1590/1981-8637201800020000153279

McCrea, S. (2009). Adjacent dentigerous cysts with the ectopic displacement of a third mandibular molar and supernumerary (forth) molar: a rare occurrence. Oral Surgery, Oral Medicine, Oral Pathology, Oral Radiology and Endodontology, 107(6), e15-e20. https://doi.org/10.1016/j.tripleo.2009.02.002

Meningaud, J. P., Oprean, N., Pitak-Arnnop, P., \& Bertrand, J. C. (2006). Odontogenic cysts: a clinical study of 695 cases. Journal of Oral Science, 48(2), 5962. https://doi.org/10.2334/josnusd.48.59

Patil, A. S., Jathar, P. N., Panse, A. M., Bahutule, S. R., Patil, R. U., \& Patil, M. (2019). Infected Dentigerous Cyst and its Conservative Management: A Report of Two Cases. International Journal of Clinical Pediatric Dentistry, 12(1), 68-72. https://doi.org/10.5005/jp-journals-10005-1578

Pereira, A. S., et al. (2018). Metodologia da pesquisa científica.

Sumer, M., Baş, B., \& Yildiz, L. (2007). Inferior alveolar nerve paresthesia caused by a dentigerous cyst associated with three teeth. Medicina Oral, Patologia Oral y Cirugia Bucal, 12(5), 388-390.

Thompson, L. D. R. (2018). Dentigerous cyst. Ear, Nose, \& Throat Journal, 97(3), 57. https://doi.org/10.1177/014556131809700317

Ustuner, E., Fitoz, S., Atasoy, C., Erden, I., \& Akyar, S. (2003). Bilateral maxillary dentigerous cysts: A case report. Oral Surgery, Oral Medicine, Oral Pathology, Oral Radiology, and Endodontics, 95(5), 632-635. https://doi.org/10.1067/moe.2003.123 